\title{
Seroprevalence, Type-Specific of Herpes Simplex Virus and Associated Risk Factors among Women of Child Bearing Age in Kogi State, Nigeria
}

\author{
Uteno Itanyi Drisu1, Francis Enifo Oronsaye ${ }^{2}$, Babatunde Ishola Gabriel Adejumo ${ }^{2 *}$, \\ Gregory Ashimedua Uchuno ${ }^{3}$, Alaba Michael Emmanuel4, Uchechukwu Dimkpa5, \\ Kingsley Ifeanyichukwu Omosor6, Margaret Oyarazi Adebowale7, \\ Oladimeji Nasiru Abdulrahman, Esmond Nwanbunwanne Ukatu ${ }^{9}$ \\ ${ }^{1}$ Department of Medical Services, Federal Polytechnic, Idah, Nigeria \\ ${ }^{2}$ Medical Laboratory Science Department, University of Benin, Benin City, Nigeria \\ ${ }^{3}$ External Quality Assurance Department, Medical Laboratory Science Council of Nigeria, Abuja, Nigeria \\ ${ }^{4}$ Medical Laboratory Science Department, College of Health Sciences and Technology, Idah, Nigeria \\ ${ }^{5}$ Physiology Department, Nnewi Campus, Nnamdi Azikiwe University, Awka, Nigeria \\ ${ }^{6}$ Shalom Diagnostic Medical Laboratory, Warri, Nigeria \\ ${ }^{7}$ Medical Laboratory Science Department, Federal School of Medical Laboratory Sciences and Health Technology, Jos, Nigeria \\ ${ }^{8}$ Medical Laboratory Science Department, College of Health Technology, Offa, Nigeria \\ ${ }^{9}$ Gulin Pharmaceauticals Nigeria Limited, Sango-Ota, Nigeria \\ Email: *babatunde.adejumo@uniben.edu, *bigadejumo@yahoo.com
}

How to cite this paper: Drisu, U.I., Oronsaye, F.E., Adejumo, B.I.G., Uchuno, G.A., Emmanuel, A.M., Dimkpa, U., Omosor, K.I., Adebowale, M.O., Abdulrahman, O.N. and Ukatu, E.N. (2018) Seroprevalence, TypeSpecific of Herpes Simplex Virus and Associated Risk Factors among Women of Child Bearing Age in Kogi State, Nigeria. Health, 10, 1006-1017.

https://doi.org/10.4236/health.2018.107075

Received: June 11, 2018

Accepted: July 23, 2018

Published: July 26, 2018

Copyright (c) 2018 by authors and Scientific Research Publishing Inc. This work is licensed under the Creative Commons Attribution International License (CC BY 4.0)

http://creativecommons.org/licenses/by/4.0/ (c) (i) Open Access

\begin{abstract}
Background: Viruses of the Herpes viridae family infect $90 \%$ of the Earth's population. Humans are the hosts of at least nine unique herpes viruses. Aim: This study is aimed at evaluating the seroprevalence of type specific herpes simplex virus infection and the associated risk factors in a cross-section of asymptomatic healthy women of childbearing age in Kogi state, Nigeria. Methodology: A total of 330 females of child bearing age (15 - 49 years) participated in this study. They were recruited from various local government areas of three Senatorial districts of Kogi state. Blood samples were collected from participants and analyzed for HSV-1 and HSV-2 antibodies (IgG) quantitatively with ELISA kit. Results: The overall prevalence of HSV was $76.7 \%$. Data further show that majority (96.4\%) of the population studied had HSV-1, while 77\% had HSV-2 infections. Results also showed that the young adults indicated prevalence of $95.7 \%$ for HSV-1 and $74.7 \%$ for HSV-2, while in the middle aged, the prevalence were $98.6 \%$ for HSV-1, and $84.9 \%$ for HSV-2. $99.2 \%$ of the married women were positive for HSV-1, while $86.9 \%$
\end{abstract}


were positive for HSV-2. $94.5 \%$ of the unmarried women were positive for HSV-1, while $70.5 \%$ were positive for HSV-2. The risk of HVS-1 or VS-2 infections was not associated with age, age of first sexual exposure and number sex partners before marriage. Married women were at greater risk for HSV-1 $(\mathrm{p}=0.03)$ and HSV-2 $(\mathrm{p} \leq 0.001)$ infections compared to the unmarried women. Conclusion: The prevalence of the HSV-1 and HSV-2 infections was high among asymptomatic healthy women of childbearing age in Kogi state, Nigeria. Efforts should be made to increase the awareness of HSV infection among the child bearing populace.

\section{Keywords}

HSV-1/HSV-2 Antibody, Infection, Women, Kogi State, Nigeria

\section{Introduction}

The epidemiology of herpes simplex is of substantial epidemiologic and public health interest. Worldwide, the rate of infection with herpes simplex virus-counting both HSV 1/HSV 2 is around 90\% [1]. Genital herpes, an infection commonly caused by human herpes simplex virus 2 (HSV-2) in Nigeria and in most regions of the world, has been described as a silent pandemic with different countries being at different stages of the epidemic [2] [3]. Although many people infected with HSV develop labial or genital lesions (herpes simplex), majority are either undiagnosed or display no physical symptoms-individuals with no symptoms are described as asymptomatic or as having subclinical herpes [4].

Most individuals contract HSV infection during the first decades of life. The prevalence of HSV 1 antibody varies from $45 \%$ to $88 \%$ in adult populations and is influenced by sex, geographic location, socio-economic status and age [5]. Antibodies to HSV-2 are rarely found before the age of onset of sexual activity, but $\mathrm{HSV}_{2}$ seroprevalence increases to $35 \%-60 \%$ by age 60 [6] [7]. This prevalence has increased dramatically since the late 70's and is highest among prostitutes (75\%) and male homosexuals (83\%) [6]. The prevalence of HSV increases with age and number of partners with women being at higher risk than men [8]. The CDC reports that $48 \%$ of African American women in the United States are infected with HSV-2 [9] [10]. The largest increase in HSV acquisition during the past few years is in white adolescents. People with many lifetime sexual partners and those who are sexually active from young age are also at higher risk for transmission of HSV-2 in United States [11] [12] [13] [14].

In Enugu state, Nigeria, Ojinmah et al., 2012 [15] reported HSV-2 prevalence of $77.9 \%$ among female patients attending skin and ANC clinics at University of Nigeria Teaching Hospital and Enugu State Teaching Hospital. Also, among children at selected hospital in Kaduna metropolis, Nigeria, Shaibu et al., 2014 [16] recorded prevalence rate of $57.8 \%$ for HSV -1 . 
The diagnosis of HVS based only on the subject medical history and physical examination is frequently inadequate, there is need to further its diagnosis using modern diagnostic techniques. There is scanty information on the prevalence of this disease in Kogi state in particular and Nigeria in general. The present study therefore was aimed at evaluating the prevalence of HSV, type specific and effects of some of its risk factors among women of reproductive age in Kogi State of Nigeria.

\section{Methodology}

\subsection{Description of the Study Area}

This research work was carried out in Kogi State, Nigeria. The state is a heterogeneous state with a population of 3,314,045 million people according to 2006 national population census. It has many ethnic groups which comprises mainly Christians and Muslims. It is a central state in Nigeria, it is bounded to the North by Federal Capital Territory Abuja; to the North-West by Kwara State and Niger State and to the South-West by Ondo State, to the South-South by Edo State and to the South-East by Anambra, Enugu and Benue States respectively. It has three senatorial districts, Kogi West, Kogi Central and Kogi East Senatorial districts respectively. The people are mainly farmers and traders, but sizeable numbers are civil servants while others are self employed. Majority of the child bearing age women in the state who participated in this work are illiterates.

\subsection{Participants}

A total number of 330 asymptomatic and apparently healthy child bearing women, aged between 18 - 49 years were recruited for this study from all the local government areas of the three Senatorial districts of the state. A well-structured questionnaire was administered to every participant of this study to obtain their demographic information and health history. Informed consents of participants were sought and obtained after explaining the purpose of the research. The Ethics Committee of Ministry of Health, Kogi State approved the study.

\subsection{Sample Collection and Processing}

An aliquot of $5 \mathrm{ml}$ venous blood obtained from each subject by peripheral venopuncture was emptied carefully into a dry sterile plain bottle to avoid lysis. The sample was allowed 1 hour to clot and retract after which it was spun using a bench centrifuge at $3000 \mathrm{rpm}$ at room temperature for 10 minutes. The serum sample was then separated from the cells within an hour into a clean sterile tube and stored at $-20^{\circ} \mathrm{C}$ prior to the analysis for $\mathrm{HSV}-1 / \mathrm{HSV}-2$ antibodies (IgG).

\subsection{Sample Analysis}

The following investigations were carried out on the sample to ascertain the status of the participants. 


\subsection{HSV-1/HSV-2 Antibody Determinations}

Antibody concentrations of all the participants to HSV-1/HSV-2 were determined using ELISA kits which were commercially purchased from Calbioteck Company, USA by following the procedure given in the kit protocol.

\subsection{Data Analysis}

Descriptive data was expressed as mean \pm standard deviation for continuous variables and percentages for categorical variables. Multinomial Logistic regression modeling was used to identify socio-demographic and behavioral risk factors that can independently predict HSV-1 and HSV-2 infections.Test of significance was set at $\mathrm{p}<0.05$. All statistics were done using SPSS/IBM software, version 20 .

\section{Results}

Figure 1 shows the prevalence of Herpes Simplex virus 1 and 2 among a cross section of adult population in Kogi State. Data shows that majority [96.4\% $(\mathrm{n}=318)]$ of the population studied had HSV-1 and 77\% $(\mathrm{n}=254)$ had HSV-2 infections.

Demographic information obtained from the participants (Table 1) show that out of the 330 subjects, 257 (77.9\%) were young adults and $73(22.1 \%)$ were middle-aged; 130 (39.4\%) were married, 200 (60.6\%) were single; 19 (5.7) were exposed to sex early (<15 years), while 192 (58.2\%) were exposed to sex from 15 years and above; $103(79.2 \%)$ had single sex partner before marriage, while 27 (20.8\%) had multiple sex partners before marriage.

Table 2 shows the prevalence and risk of HSV-1/HSV-2 according to the age of subjects. Data shows that the young adults (18-35 years) indicated prevalence of $95.7 \%$ for HSV-1 and $74.7 \%$ for HSV-2, while in the middle aged, the prevalence were $98.6 \%$ for HSV-1, and $84.9 \%$ for HSV-2. Multivariate logistic regression analysis further indicated that young adults did not indicate significantly greater risk for HSV-1 $(\mathrm{p}=0.47)$ and HSV-2 $(\mathrm{p}=0.08)$ seropositivity compared to the middle-aged adults.

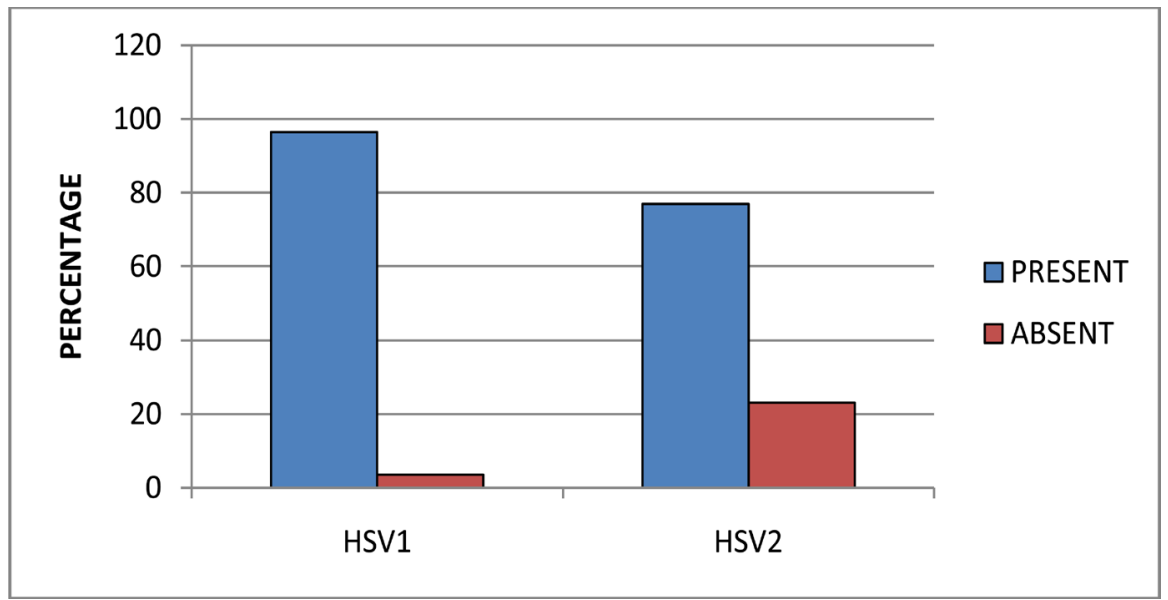

Figure 1. The prevalence of Herpes Simplex Virus 1 (HSV 1) and Herpes Simplex Virus 2 (HSV 2) in Kogi State. 
Table 1. Distribution of the study population according to their demographic characteristics and sexual behaviors.

\begin{tabular}{ccc}
\hline Characteristics & Frequency & Percentage \\
\hline Age Group & & \\
Young & 257 & 77.9 \\
Middle-aged & 73 & 22.1 \\
Marital Status & & \\
Married & 130 & 39.4 \\
Single & 200 & 60.6 \\
& & \\
Age of First Sexual Exposure & 19 & 5.7 \\
$<15$ years & 192 & 58.2 \\
$\geq 15$ years & 119 & 36.1 \\
No Response & & \\
& & \\
Single & 103 & 79.2 \\
Multiple & 27 & 20.8 \\
\hline
\end{tabular}

Table 2. The prevalence and risk of HSV-1 and HSV-2 according to age of participants.

\begin{tabular}{ccccccc}
\hline \multirow{2}{*}{$\begin{array}{c}\text { Type of } \\
\text { Infection }\end{array}$} & \multirow{2}{*}{ Age Group } & \multicolumn{3}{c}{ Status of Infection } & \multicolumn{2}{c}{ Statistics } \\
\cline { 3 - 7 } & & Present & $\begin{array}{c}\text { Absent } \\
\mathrm{N}(\%)\end{array}$ & $\begin{array}{c}\text { Total } \\
\mathrm{N}(\%)\end{array}$ & OR (C.I.) & P-Value \\
\hline \multirow{2}{*}{ HVS-1 } & Young & $246(95.7)$ & $11(4.3)$ & $257(100)$ & $0.31(0.01-2.38)$ & 0.47 \\
& Middle-aged & $72(98.6)$ & $1(1.4)$ & $73(100)$ & & \\
& Young & $192(74.7)$ & $65(25.3)$ & $257(100)$ & $0.52(0.24-1.10)$ & 0.08 \\
HVS-2 & Middle-aged & $62(84.9)$ & $11(15.1)$ & $73(100)$ & &
\end{tabular}

Abbreviations: $\mathrm{OR}=$ Odds Ratio; $\mathrm{CI}=$ Confidence Interval.

Table 3. Prevalence and risk of HSV-1 and HSV-2 according to the marital status of the participants.

\begin{tabular}{|c|c|c|c|c|c|c|}
\hline \multirow{2}{*}{$\begin{array}{l}\text { Type of } \\
\text { Infection }\end{array}$} & \multirow{2}{*}{$\begin{array}{c}\text { Marital } \\
\text { Status }\end{array}$} & \multicolumn{3}{|c|}{ Status of Infection } & \multicolumn{2}{|c|}{ Statistics } \\
\hline & & $\begin{array}{c}\text { Present } \\
\mathrm{N}(\%)\end{array}$ & $\begin{array}{l}\text { Absent } \\
\mathrm{N}(\%)\end{array}$ & $\begin{array}{l}\text { Total } \\
\text { N (\%) }\end{array}$ & OR (C.I.) & p-Value \\
\hline \multirow{2}{*}{ HVS-1 } & Married & $129(99.2)$ & $1(0.8)$ & $130(100)$ & \multirow{2}{*}{$7.50(1.0-157.5)$} & \multirow{2}{*}{0.03} \\
\hline & Single & $189(94.5)$ & $11(5.5)$ & $200(100)$ & & \\
\hline \multirow{2}{*}{ HVS-2 } & Married & $113(86.9)$ & $17(13.1)$ & $130(100)$ & \multirow{2}{*}{$2.78(1.48-5.26)$} & \multirow{2}{*}{$<0.001$} \\
\hline & Single & $141(70.5)$ & $59(29.5)$ & $200(100)$ & & \\
\hline
\end{tabular}

Table 3 shows the prevalence and risk of HSV-1 and HSV-2 according to the marital status of the participants. One hundred and twenty nine (99.2\%) of the married women were positive for HSV-1, while $1(0.8 \%)$ was negative. One hundred and thirteen (86.9\%) of the married women were positive for HSV-2, 
while 17 (13.1\%) were negative. One hundred and eighty nine (94.5\%) of the unmarried women were positive for HSV-1, while 11 (5.5\%) were negative. One hundred and forty one (70.5\%) were positive for HSV-2 and 59 (29.5\%) were negative for HSV-2 respectively among the unmarried participants. Multivariate logistic regression analysis indicated that married women were at significantly greater risk for HSV-1 ( $\mathrm{p}=0.03)$ and HSV-2 $(\mathrm{p} \leq 0.001)$ infections compared to the unmarried women.

Nineteen (100\%) of the participants who had sexual intercourse before the age of 15 years were all positive for HSV-1 (Table 4). Fifteen (78.9\%) of them were positive for HSV-2 while 4 (21.1\%) were negative. One hundred and eighty nine (98.4\%) of the 192 participants who had sexual intercourse after 15 years, were positive for HSV-1, while 3 (1.6\%) were negative. One hundred and fifty five (80.7\%) were positive for HSV-2 and 37(19.3\%) were negative. Of the 330 participants, 119 (36.06\%) declined to give information on the time of their first exposure to sexual intercourse. Multivariate logistic regression test indicated that participants who had sexual intercourse before the age of 15 years were not at greater risk of HSV-1 $(\mathrm{p}=1.00)$ and HSV-2 $(\mathrm{p}=0.76)$ infection compared to those first exposed to sexual intercourse from 15 years of age and above.

All the married participants $130(100 \%)$ volunteered information of having sexual partners before marriage (Table 5). One hundred and three had just single sexual partner before marriage, out of which 102 (99\%) were positive for HSV-1 and $1(0.97 \%)$ was negative. Twenty seven (100\%) of the participants

Table 4. Prevalence and risk of HSV-1 and HSV-2 according to age of first sexual exposure among the participants.

\begin{tabular}{ccccccc}
\hline \multirow{2}{*}{$\begin{array}{c}\text { Type of } \\
\text { Infection }\end{array}$} & Age of First & \multicolumn{3}{c}{ Status of Infection } & \multicolumn{2}{c}{ Statistics } \\
\cline { 3 - 6 } & Sexual Exposure & $\begin{array}{c}\text { Present } \\
\mathrm{N}(\%)\end{array}$ & $\begin{array}{c}\text { Absent } \\
\mathrm{N}(\%)\end{array}$ & $\begin{array}{c}\text { Total } \\
\mathrm{N}(\%)\end{array}$ & OR (C.I.) & P-Value \\
\hline \multirow{2}{*}{ HVS-1 } & $<15$ years & $19(100)$ & $0(0)$ & $19(100)$ & Inf. (0.04 - Inf.) & 1.00 \\
& $\geq 15$ years & $189(98.4)$ & $3(1.6)$ & $192(100)$ & & 0.76 \\
HVS-2 & $<15$ years & $15(78.9)$ & $4(21.1)$ & $19(100)$ & $0.89(0.25-3.40)$ & $0.72(100)$ \\
\hline
\end{tabular}

Table 5. Prevalence and risk of HSV-1 and HSV-2 among the married participants according to number of sexual partners before marriage.

\begin{tabular}{|c|c|c|c|c|c|c|}
\hline \multirow{2}{*}{$\begin{array}{l}\text { Type of } \\
\text { Infection }\end{array}$} & \multirow{2}{*}{$\begin{array}{c}\text { Number of Sex } \\
\text { Partners Before } \\
\text { Marriage }\end{array}$} & \multicolumn{3}{|c|}{ Status of Infection } & \multicolumn{2}{|c|}{ Statistics } \\
\hline & & $\begin{array}{l}\text { Present } \\
\mathrm{N}(\%)\end{array}$ & $\begin{array}{l}\text { Absent } \\
\mathrm{N}(\%)\end{array}$ & $\begin{array}{l}\text { Total } \\
\text { N (\%) }\end{array}$ & OR (C.I.) & P-Value \\
\hline \multirow{2}{*}{ HVS-1 } & Single & $102(99.0)$ & $1(0.97)$ & $103(100)$ & \multirow{2}{*}{ Inf. (0.01 - Inf.) } & \multirow[b]{2}{*}{1.00} \\
\hline & Multiple & $27(100)$ & $0(0)$ & $27(100)$ & & \\
\hline \multirow{2}{*}{ HVS-2 } & Single & $81(78.6)$ & $22(21.4)$ & $103(100)$ & \multirow{2}{*}{$0.95(0.31-3.0)$} & \multirow[b]{2}{*}{1.00} \\
\hline & Multiple & $21(77.8)$ & $6(22.2)$ & $27(100)$ & & \\
\hline
\end{tabular}


who had more than 1 sex partner (comprising 20 with 2 partners, 6 with 3 partners and 1 with 4 partners and above) were all positive for HSV-1. Eighty one (78.6\%) of the 103 married women that had a single sexual partners were positive for HSV-2, while 22 (21.4\%) were negative. Twenty one $(77.8 \%)$ of those who had more than 1 sex partner (comprising 15 with 2 partners, 5 with 3 partners and 1 with 4 partners and above) were positive for HSV-2, while, 6 (22.2\%) were negative for HSV-2. Multivariate logistic regression test indicated that participants who had more than one sexual partners before marriage were not at greater risk of HSV-1 $(\mathrm{p}=1.00)$ or HSV-2 $(\mathrm{p}=1.00)$ infection compared to those who had a single sexual partner before marriage.

\section{Discussion}

The overall prevalence of HSV in the studied population is $76.7 \%$. Our study indicated HSV-1 prevalence of $96.4 \%$. This agrees with a previous study [17] done in the following countries; Bulgaria (83.9\%), Czech Republic (80.6\%). Also in agreement with this high prevalence rate are the works done in the Middle East [18]. In Turkey they found the prevalence of HSV-1 to be $97 \%$ among pregnant women in Erzurum in Eastern Anatolia Region. However, in Istabul, 85.3\% was found to be positive for HSV-1 among sexually active adults. Prevalence of these viruses was higher in sex workers of lstabul, reaching levels of $99 \%$ and $60 \%$ for HSV 1/HSV 2 respectively. Ibrahim et al., 2000 [19] reported 95\% level of HSV-1 positivity among the Syrians, while Cunningham et al., [20] reported $76.5 \%$ prevalence of HSV-1 in Australia. However, low prevalence of HSV-1 was reported in Belgium (67.4\%), Netherlands (56.7\%), and Finland (52.4\%) respectively [17]. In Asia, a lower prevalence of HSV-1 was found among Thailand women (51\%), and $50 \%-60 \%$ in Japan [18] [21]. Kaur et al. [22] reported 33.3\% prevalence of HSV-1 in India and 59.8\% in Israel [23]. Among children at selected Hospitals in Kaduna metropolis, Nigeria, Shaibu et al., 2014 [16] recorded prevalence rate of $57.8 \%$ for HSV-1.

This work recorded 77\% prevalence rate for HSV-2. This is in agreement with the work done in Enugu state, Nigeria [15]. They reported HSV-2 prevalence of $77.9 \%$ among female patients attending skin and ANC clinics at University of Nigeria Teaching Hospital and Enugu State Teaching Hospital. In contrast, a previous work by Pebody et al., 2004 [17] indicated prevalences of $23.9 \%$ in Bulgaria, $13.9 \%$ in Germany, Finland (13.45\%), Belgium(11.1\%), Netherland (8.8\%), the Czech Republic (6.0\%) and England and Wales (4.2\%) respectively. HSV-2 seroprevalence is high in Central and South America. Infection levels are estimated at $20 \%$ to $60 \%$ [18] [24]. HSV-2 is more common in Sub-Saharan Africa than in Europe or the North America. Up to 82\% of women and 53\% of men in Sub-Saharan Africa are seropositive for HSV-2. These are the highest levels of HS-2 infection in the world, although exact levels vary from country to country in this continent, [24]. Genital herpes appears less common in Northern Africa compared to Sub-Saharan Africa. For example, only $26 \%$ of middle-aged women 
have antibodies for HSV 2 in Morocco [25]. The prevalence of HSV 2 in Thailand is $37 \%$, while $9 \%$ was recorded in Philippines (25). Much works have been done in the Middle East on HSV 2. Of these works were the one done among the pregnant women in Erzurum in Eastern Anatolia Region in Turkey (42\%) [18], lstabul (4.8\%) [26], Jordan (52.8\%, men), and $41.5 \%$ (women) [27] and Israel (9.2\%) [23]. Cunningham et al., 2006 [20] found out in Australia that the prevalence of HSV 2 is $12 \%$ (women $16 \%$, men $8 \%$ respectively). The number of genital herpes infections appears to be rising in New Zealand with three times more cases in 1993 compared to 1977 [28], where HSV 2 affects 60\% more women than men of similar age [18].

It is noteworthy that there are limited studies done on the prevalence of herpes simplex virus infection in Nigeria. It is believed that the high prevalence of HSV infection observed in this study may be explained in part by the low awareness of the prevalence and risk factors of this viral infection and lack of sensitization of the general population to avail themselves for the HSV tests. It may also be a pointer to indiscrete sexual behavior among the studied group.

The present study further indicated prevalence of $95.7 \%$ and $74.7 \%$ for HSV-1 and HSV-2 respectively among young adults (18 - 35 years). In middle-aged adults the prevalence for HSV-1 and HSV-2 were $98.6 \%$ and $84.9 \%$ respectively. The present findings appeared relatively higher compared with studies done elsewhere among different age groups. For example, a previous study by $\mathrm{Xu}$ et al., 2010 [29], reported a prevalence of $16.2 \%$ among Americans aged 14 to 49 who were infected with HSV-2. Also in Ontario, the prevalence of HSV-2 in people between the ages of 15 to 16 has been shown to be $26.9 \%$ for men and $32 \%$ for non-pregnant women [30]. During the mid-1980s, HSV-2 prevalence was $33 \%$ in 25 to 29 -year-old women and $45 \%$ in those aged 40 and over in Costa Rica. In the early 1990s HSV-2 prevalence was approximately $45 \%$ among women over 60 in Mexico [18]. The prevalence of HSV-2 in middle aged Colombian women was $60 \%$ and $54 \%$ in Haiti, while HSV-2 antibodies were found in more than $41 \%$ of women of child bearing age in Brazil [18]. In South Korea, the prevalence of HSV-2 in those less than 20 years is $2.7 \%$ for men, and $3.0 \%$ for women, while for those over 20 years, the prevalence was $21.7 \%$ for men and $28 \%$ for women [31]. Our data also showed that the young adults were not at greater risk of the HSV-1 and HSV-2 infections compared with the middle-aged adults. A previous study [32] reported that HSV-2 prevalence consistently increased with age in all geographic areas. Another study [33] also demonstrated that older age was associated with significantly higher odds of HSV-2 infection.

Our findings also indicated that married women were at significantly greater risk for HSV-1 and HSV-2 infections compared to the unmarried women. It is not very clear the reason for the higher risk in married women compared to the unmarried. It is however thought that those who were married were more likely to have had a past-year sex partner compared with those who were single. A previous study [34] has shown that relationship status remained an independent 
predictor of HSV-2 with the married status being protective for HSV-2 in those aged 30 - 49 years.

Our data which indicated high prevalence of HSV infection in subjects who were exposed to sex early and those with multiple sex partners agrees with work done in Istabul [26] among sex workers, which reported prevalence of $99 \%$ and $66 \%$ for HSV-1 and HSV-2 respectively. In contrast, a lower seroprevalence of $34 \%$ for HSV-1 and 20\% HSV-2 were recorded in Syria among the prostitutes and bar girls who are considered to be the high risk group [19]. These findings demonstrate that the high incidence of HVS infection in most part of the world may result from early exposure to sex and multiple sex partners. However, it is noteworthy that in the present study those who had early exposure to sex and those who had multiple sex partners before marriage were not at greater risk of HSV infection compared with those who had late exposure to sex and those with single sex partners before marriage. A previous study [35] has shown that women who commenced sexual activity at 15 or younger age and those with more than one sexual partner before marriage were at greater risk of HSV compared to women who delayed sexual exposure until they were above 15 years and those who had single sex partner before marriage.

\section{Conclusion}

The prevalence of HSV-1 and HSV-2 infections is high in Kogi state. Marital status played an important role for HSV-2 and HSV-1 infections. These findings therefore indicate that health education and screening interventions are highly required, in an effort to prevent transmission to other individuals, including sex partners and offspring. There is also the need to intensify efforts toward HSV1 and HSV2 vaccine development by the government and health institutions. Furthermore, early sex education among teenagers and continuous sex education should be encouraged among the adults.

\section{Acknowledgements}

We acknowledge the Ministry of Health, Kogi State for ethical approval, and the participants within all the local Government areas of Kogi state.

\section{Conflicts of Interest}

None.

\section{Funding}

The research was privately funded. No grant or sponsorship from anywhere.

\section{References}

[1] Wald, A. and Corey, L. (2007) Chapter 36: Persistence in the Population: Epidemiology, Transmission. Human Herpesviruses: Biology, Therapy, and Immunoprophylaxis, Cambridge University Press, Cambridge. 
[2] Looker, K.J., Garnett, G.P. and Schmid, G.P. (2008) An Estimate of the Global Prevalence and Incidence of Herpes Simplex Virus Type 2 Infection. Bulletin of the World Health Organization, 86, 737-816. https://doi.org/10.2471/BLT.07.046128

[3] Oni, A.A., Adu, F.D., Ekweozor, C.C. and Bakare, R.A. (1996) Genital Herpes Simplex Virus Infection in Females in Ibadan Nigeria. West African Journal of Medicine, 15, 107-110.

[4] Handsfield, H.H. (2000) Public Health Strategies to Prevent Genital Herpes: Where Do We Stand? Current Infectious Disease Reports, 2, 25-30. https://doi.org/10.1007/s11908-000-0084-y

[5] Whitley, R.W. and Roizman, B. (2001) Herpes Simplex Virus Infections. Lancet, 357, 1513. https://doi.org/10.1016/S0140-6736(00)04638-9

[6] Nahmias, A.J., Lee, F.K. and Beckmanahmias, S. (1990) Sera-Epidemiological and -Sociological Patterns of Herpessimplex Virus Infection in the World. Scandinavian Journal of Infectious Diseases. Supplementum, 69, 19-36.

[7] Fleming, D.T. and Wasserheit, J.N. (1999) From Epidemiological Synergy to Public Health Policy and Practice: The Contribution of Other Sexually Transmitted Diseases to Sexual Transmission of HIV Infection. Sexually Transmitted Infections, 75, 3-17. https://doi.org/10.1136/sti.75.1.3

[8] Fatahzadeh, M. and Schwartz, R.A. (2007) Human Herpes Simplex Virus Infections: Epidemiology, Pathogenesis, Symptomatology, Diagnosis, and Management. Journal of the American Academy of Dermatology, 57, 737-766. https://doi.org/10.1016/j.jaad.2007.06.027

[9] CDC: Genital Herpes Rates Still High. Centers for Disease Control and Prevention.

[10] UPDATE: CDC Stands Behind Report That Half of Black Women Have Herpes. NewsOne.

[11] Herpes Simplex. University of Maryland Medical Center.

[12] LEARN ABOUT HERPES > Fast Facts. ASHA Herpes Resource Center.

[13] STD Facts-Genital Herpes. Centers for Disease Control and Prevention.

[14] Herpes. Stanford University Sexual Health Peer Resource Center.

[15] Ojinmah, U.R., Nnoruka, E.N., Ozoh, G.A., Onyekonwu, C.L. and Aguwa, E.N. (2012) Herpes Simplex Virus Type 2 Infection among Females in Enugu, Enugu State. Nigerian Journal of Medicine, 21, 394-403.

[16] Shaibu, A.M., Aminu, M., Musa, B.O.P. and Bugaje, M.A. (2014) Seroprevalence of IgG Antibodies to Herpes Simplex Virus Type-1 in Nigerian Children. Nigerian Journal of Medicine, 23, 40-45.

[17] Pebody, R.G., Andrews, N., Brown, D., et al. (2004) The Seroepidemiology of Herpes Simplex Virus Type 1 and 2 in Europe. Sexually Transmitted Infections, 80, 185-191. https://doi.org/10.1136/sti.2003.005850

[18] Smith, J.S., Herrero, R., Muñoz, N., et al. (2001) Prevalence and Risk Factors for Herpes Simplex Virus Type 2 Infections among Middle-Age Women in Brazil and the Philippines. Sexually Transmitted Diseases, 28, 187-194. https://doi.org/10.1097/00007435-200104000-00001

[19] Ibrahim, A.I., Kouwatli, K.M. and Obeid, M.T. (2000) Frequency of Herpes Simplex Virus in Syria Based on Type-Specific Serological Assay. Saudi Medical Journal, 21, 355-360.

[20] Cunningham, A.L., Taylor, R., Taylor, J., Marks, C., Shaw, J. and Mindel, A. (2006) Prevalence of Infection with Herpes Simplex Virus Types 1 and 2 in Australia: A Nationwide Population Based Survey. Sexually Transmitted Infections, 82, 164-168. 
https://doi.org/10.1136/sti.2005.016899

[21] Patrick, D.M., Dawar, M., Cook, D.A., Krajden, M., Ng, H.C. and Rekart, M.L. (2001) Antenatal Seroprevalence of Herpes Simplex Virus Type 2 (HSV-2) in Canadian Women: HSV-2 Prevalence Increases throughout the Reproductive Years. Sexually Transmitted Diseases, 28, 424-428. https://doi.org/10.1097/00007435-200107000-00011

[22] Kaur, R., Gupta, N. and Baveja, U.K. (2005) Seroprevalence of HSV-1/HSV-2 Infections in Family Planning Clinic Attenders. The Journal of Communicable Diseases, 37, 307-309.

[23] Davidovici, B.B., Green, M., Marouni, M.J., Bassal, R., Pimenta, J.M. and Cohen, D. (2006) Seroprevalence of Herpes Simplex Virus 1 and 2 and Correlates of Infection in Israel. Journal of Infection, 52, 367-373. https://doi.org/10.1016/j.jinf.2005.08.005

[24] Weiss, H. (2004) Epidemiology of Herpes Simplex Virus Type 2 Infection in the Developing World. Herpes, 11, 24A-35A.

[25] Patnaik, P., Herrero, R., Morrow, R.A., et al. (2007) Type-Specific Seroprevalence of Herpes Simplex Virus Type 2 and Associated Risk Factors in Middle-Aged Women from 6 Countries: The IARC Multicentric Study. Sexually Transmitted Diseases, 34, 1019-1024. https://doi.org/10.1097/OLQ.0b013e31811f4118

[26] Dolar, N., Serdaroglu, S., Yilmaz, G. and Ergin, S. (2006) Seroprevalence of Herpes Simplex Virus Type 1 and Type 2 in Turkey. Journal of the European Academy of Dermatology and Venereology, 20, 1232-1236. https://doi.org/10.1111/j.1468-3083.2006.01766.x

[27] Abuharfeil, N. and Meqdam, M.M. (2000) Seroepidemiologic Study of Herpes Simplex Virus Type 2 and Cytomegalovirus among Young Adults in Northern Jordan. New Microbiologica, 23, 235-239.

[28] Lyttle, P.H. (1994) Surveillance Report: Disease Trends at New Zealand Sexually Transmitted Disease Clinics 1977-1993. Genitourinary Medicine, 70, 329-335. https://doi.org/10.1136/sti.70.5.329

[29] Xu, F., Sternberg, M.R., Gottlieb, S.L., Berman, S.M., Markowitz, L.E. and Forhan, S.E. (2010) Seroprevalence of Herpes Simplex Virus Type 2 among Persons Aged 14-49 Years-United States, 2005-2008. Morbidity and Mortality Weekly Report, 59, 456-459.

[30] Howard, M., Sellors, J.W., Jang, D., et al. (2003) Regional Distribution of Antibodies to Herpes Simplex Virus Type 1 (HSV-1) and HSV-2 in Men and Women in Ontario, Canada. Journal of Clinical Microbiology, 41, 84-89. https://doi.org/10.1128/JCM.41.1.84-89.2003

[31] Shin, H.S., Park, J.J., Chu, C., et al. (2007) Herpes Simplex Virus Type 2 Seroprevalence in Korea: Rapid Increase of HSV-2 Seroprevalence in the 30s in the Southern Part. Journal of Korean Medical Science, 22, 957-962. https://doi.org/10.3346/jkms.2007.22.6.957

[32] Smith, J.S. and Robinson, J.N. (2002) Age-Specific Prevalence of Infection with Herpes Simplex Virus Types 2 and 1: A Global Review. The Journal of Infectious Diseases, 186, S3-S28. https://doi.org/10.1086/343739

[33] Patel, P., Bush, T., Mayer, K.H., Desai, S., Henry, K., Overton, E.T., et al. (2012) Prevalence and Risk Factors Associated with Herpes Simplex Virus-2 Infection in a Contemporary Cohort of HIV-Infected Persons in the United States. Sexually Transmitted Diseases, 39, 154-160. https://doi.org/10.1097/OLQ.0b013e318239d7fd

[34] Bauer, G.R., Khobzi, N. and Coleman, T.A. (2010) Herpes Simplex Virus Type 2 Seropositivity and Relationship Status among U.S. Adults Age 20 to 49: A Popula- 
tion-Based Analysis. BMC Infectious Diseases, 10, 359.

https://doi.org/10.1186/1471-2334-10-359

[35] Tideman, R., Taylor, J., Marks, C., Seifert, C., Berry, G., Trudinger, B., et al. (2001) Sexual and Demographic Risk Factors for Herpes Simplex Type 1 and 2 in Women Attending an Antenatal Clinic. Sexually Transmitted Infections, 77, 413-415. https://doi.org/10.1136/sti.77.6.413 